\title{
Physiological changes associated with the production of defective egg-shells by hens receiving sodium chloride in the drinking water
}

\author{
BY D. BALNAVE ${ }^{1}$, I. YOSELEWITZ ${ }^{1}$ AND R. J. DIXON \\ ${ }^{1}$ Department of Animal Husbandry and ${ }^{2}$ Department of Veterinary Clinical Studies, \\ University of Sydney, Werombi Road, Camden, NSW 2570, Australia
}

(Received 26 February 1988 - Accepted 9 September 1988)

\begin{abstract}
1. Supplementing the drinking water of laying hens with 600 or $2000 \mathrm{mg}$ sodium chloride/l induced large increases in egg-shell defects without corresponding changes in egg production, egg weight or food and water intakes. A supplement of $2000 \mathrm{mg} \mathrm{NaCl} / 1$ resulted in a high incidence of shell-less eggs.

2. The increased incidence of egg-shell damage in hens receiving the $\mathrm{NaCl}$ was associated with a decrease in eggshell quality measured objectively. These responses persisted even after the $\mathrm{NaCl}$ was removed from the drinking water.

3. The $\mathrm{NaCl}$ treatment had little effect on blood acid-base balance and electrolytes, but significant reductions were observed in the carbon dioxide tension, and bicarbonate and calcium concentrations in the fluid surrounding the egg in the shell gland.

4. The poor shell quality appeared to be associated with a reduced supply of bicarbonate, rather than with an effect on $\mathrm{Ca}$, in the lumen of the shell gland, although a reduced residence time of eggs in the shell gland may also have contributed to the problem.
\end{abstract}

Recent studies in this department have shown that the addition of sodium chloride to the drinking water of laying hens increases the incidence of egg-shell defects (Balnave \& Scott, 1986; Balnave \& Yoselewitz, 1987; Yoselewitz et al. 1988). In the most recent work (Yoselewitz et al. 1988) supplements of $600 \mathrm{mg} \mathrm{NaCl} / 1$ increased egg-shell defects from 4 to $11 \%$, in keeping with earlier observations of a two- to threefold increase with this level of supplementation. When $2000 \mathrm{mg} \mathrm{NaCl} / 1$ were given, more than half the eggs produced had defective shells. Furthermore, not all hens were affected to the same degree by the $\mathrm{NaCl}$ treatment and some continued to lay normal eggs with good egg-shell quality. However, more hens were affected at the higher concentration of $\mathrm{NaCl}$. Dietary supplementation with calcium carbonate failed to remedy the problem and measurements of blood acid-base balance and electrolytes, including calcium and bicarbonate, failed to detect any major changes which could be associated with the large increase in egg-shell defects resulting from. the $\mathrm{NaCl}$ treatment.

The present studies were carried out in an attempt to identify the biological lesion associated with the increased incidence of egg-shell defects resulting from supplementation of the drinking water with $\mathrm{NaCl}$. Observations of production characteristics and blood variables were extended to an examination of the composition of the shell-gland fluid from individual hens.

\section{MATERIALS AND METHODS \\ Birds and housing}

In Expt 1, twenty-four hens (White Leghorn $\times$ Australorp) in their second laying year (105 weeks of age) were used. In this experiment two treatments (unsupplemented municipal tap-water or this water supplemented with $2000 \mathrm{mg} \mathrm{NaCl} / 1$ ) were compared in a windowless, temperature-controlled room maintained at $25^{\circ}$. Eight stacks of three individually caged hens were used, four stacks being randomly allocated as replicates to each treatment. 
In Expt 2, 1140 hens (White Leghorn $\times$ Australorp) in their first laying year (58 weeks of age) were used. This experiment was a factorial design of three water treatments (unsupplemented, 600 or $2000 \mathrm{mg} \mathrm{NaCl} / 1$ ) and two diets (layer mash or breeder crumbles). Six single-deck, double rows of ninety-five adjacently caged hens/row with a common water trough were housed in a commercial layer shed. Each treatment combination was assigned to two groups of ninety-five hens. The two diets were randomly allocated to each double row of cages and the three water treatments were randomly allocated to each of two water troughs. A light period of $16 \mathrm{~h} / \mathrm{d}$ was provided in each experiment.

\section{Food and water}

Hens in both experiments were given free access to food and water. They were fed on a proprietary layer mash in Expt 1, whereas in Expt 2 half the hens received the layer mash and the remainder were given proprietary layer breeder crumbles. The crumbles were given in case the responses to the layer mash were due to physical separation of dietary components or to hens choosing not to eat the $\mathrm{Ca}$ component in the layer mash. The calculated compositions of the mash and crumbles were respectively $(/ \mathrm{kg}): 160$ and $163 \mathrm{~g}$ crude protein (nitrogen $\times 6.25$ ), 11.5 and $11.1 \mathrm{MJ}$ metabolizable energy, 1.8 and $1.4 \mathrm{~g}$ sodium, 4.4 and $5.3 \mathrm{~g}$ potassium, 35 and $36 \mathrm{~g} \mathrm{Ca}$ and 2.4 and $2.2 \mathrm{~g}$ chloride.

Municipal tap-water $(\mathrm{pH} \mathrm{7.0)}$ containing $(\mathrm{mmol} / \mathrm{l}): 1 \cdot 8 \mathrm{Na},<1 \mathrm{Cl}, 0 \cdot 1 \mathrm{~K}$ was provided as drinking water. Supplements of $2000 \mathrm{mg} \mathrm{NaCl} / 1(34 \cdot 2 \mathrm{mmol} / \mathrm{l})$ (Expts 1 and 2) and $600 \mathrm{mg} \mathrm{NaCl} / 1(10.3 \mathrm{mmol} / 1)$ (Expt 2) were provided to some hens for a period of 5 weeks in each experiment. The $\mathrm{NaCl}$ solutions were prepared as required and stored in 50 -litre covered plastic drums.

\section{Egg collection and egg-shell-quality measurements}

All eggs were collected and inspected manually since previous experience had shown that approximately $40 \%$ of all egg-shell damage consisted of thin cracks which were difficult to detect by conventional candling procedures. Egg-shell-quality measurements were carried out as described previously (Balnave \& Yoselewitz, 1987).

\section{Blood and shell-gland-fluid measurements}

Blood ( $4 \mathrm{ml})$ was drawn from the brachial vein into a syringe containing lithium heparin. Air was expelled and the syringe sealed immediately with a plastic cap to prevent loss of carbon dioxide. Immediately afterwards a sample of fluid from the shell gland was collected into another syringe by the method described by El Jack \& Lake (1967). Air was immediately expelled and the syringe sealed to prevent loss of $\mathrm{CO}_{2}$. All samples were stored in ice until analysed. The partial pressure of $\mathrm{CO}_{2}\left(p_{\mathrm{CO}_{2}}\right)$, concentration of bicarbonate ions and $\mathrm{pH}$ of blood and shell-gland fluid, corrected to body temperature of $41^{\circ}$, were measured within $1.5 \mathrm{~h}$ using an acid-base laboratory ABL3 Radiometer (Radiometer A/S, Denmark) and plasma and shell-gland-fluid electrolytes were determined using a Nova 1 ion selective electrode photometer (Nova Biomedical, USA) and a Corning 925 chloride analyser (Corning, UK). The total $\mathrm{Ca}$ concentrations in plasma and shell-gland fluid were determined with methylthymol blue using a Cobas Mira photometric system (Hoffmann La Roche, Switzerland). Instruments were calibrated daily according to the manufacturers' recommendations using external standards; coefficients of variation for the plasma ions (thirteen estimates) were (\%): $\mathrm{Na} 0 \cdot 6, \mathrm{~K} 1 \cdot 2, \mathrm{Cl} 1 \cdot 1, \mathrm{Ca} 2 \cdot 2$.

\section{Expt 1}

Egg production and egg-shell damage, including the production of soft-shelled (shell-less) eggs, were recorded daily. Shell-quality measurements were made on all eggs on the final 
three consecutive days of each of the first 4 weeks and during each day of the final week of the experiment. Egg weight was recorded before the egg-shell-quality measurements. Food intake was recorded weekly. Drinking water was provided in troughs attached to each set of six cages. The water intake of each group of six hens was measured over the complete experiment without any adjustment being made for evaporative loss which was assumed to be similar for all groups. The time of oviposition for all eggs laid during the final 4 weeks of the experiment was recorded every $30 \mathrm{~min}$ during the daily daylight period.

After 5 weeks hens were identified from the recorded oviposition times as being due to lay within $2 \mathrm{~h}$ and those with a hard-shelled egg in the shell gland were used to examine the compositions of blood and shell-gland fluid. It was not possible to obtain blood and shell-gland fluid from all hens, since some birds did not produce eggs at this time and in a number of cases insufficient fluid was obtained from the shell gland to enable analyses to be performed. Samples from both sources were obtained from a total of four hens receiving the unsupplemented water and six hens receiving the $\mathrm{NaCl}$. All but one of the twenty-four hens receiving the $\mathrm{NaCl}$ treatment, including the six hens sampled, were consistently laying eggs with damaged shells.

\section{Expt 2}

Egg production was recorded daily and egg-shell damage estimated on the final three consecutive days of each week. Soft-shelled egg production could not be determined accurately in the facilities used. Food and water intakes were recorded weekly and egg weight and egg-shell-quality measurements made on all eggs laid on the final day of week 5.

At the end of the 5-week experimental period shell-gland fluid was collected from some hens receiving the proprietary layer mash. Samples were taken from ten hens receiving the unsupplemented water and laying good-quality eggs, six hens receiving the unsupplemented water and consistently laying cracked eggs and ten hens receiving $2000 \mathrm{mg} \mathrm{NaCl} / 1$ and consistently laying cracked eggs. Samples were taken from hens with a hard-shelled egg in the shell gland between 4 and $5 \mathrm{~h}$ after the onset of daylight.

The $\mathrm{NaCl}$ treatments were discontinued and all hens allowed free access to municipal tap-water for 11 weeks before shell-gland-fluid samples were again taken from some hens fed on the proprietary layer mash and previously receiving the unsupplemented and $2000 \mathrm{mg} \mathrm{NaCl} / 1$ water treatments. Samples were taken from ten hens producing normal eggs and ten hens producing cracked eggs on each treatment. The hens were selected at random on the basis of egg-shell defects determined manually on three consecutive days during each of the 4 weeks before sampling, i.e. weeks 8-11 after the removal of $\mathrm{NaCl}$ from the drinking water.

\section{Statistical analyses}

The values for the production variables and egg-quality measurements in both experiments, based on group mean values, were analysed by factorial analysis of variance. Blood and shell-gland-fluid values were analysed by Student's $t$ test (Steel \& Torrie, 1982). Linear regression equations relating physiological aspects of egg production in the oviduct to the concentration of $\mathrm{HCO}_{3}{ }^{-}$in shell-gland fluid were also developed for the six hens receiving $2000 \mathrm{mg} \mathrm{NaCl} / 1$ in Expt 1.

\section{RESULTS}

Supplementing the drinking water with $\mathrm{NaCl}$ significantly $(P<0.001)$ increased the incidence of egg-shell damage in both experiments without any significant effect being 
Table 1. Expts 1 and 2. Mean egg-shell damage and production variables of laying hens receiving sodium chloride in their drinking water

(Hens were fed on a proprietary layer mash (diet 1) in Expt 1 and either this diet or proprietary layer breeder crumbles (diet 2) in Expt 2; for details of experimental procedures, see pp. 36-37)

\begin{tabular}{|c|c|c|c|c|c|c|}
\hline $\begin{array}{l}\text { Supplement } \\
\text { of } \mathrm{NaCl} \\
(\mathrm{mg} / \mathrm{l})\end{array}$ & $n$ & $\begin{array}{c}\text { Damaged } \\
\text { shells } \\
\text { (/100 eggs) }\end{array}$ & $\begin{array}{c}\text { Egg } \\
\text { production } \\
\text { (/bird day) }\end{array}$ & $\begin{array}{l}\text { Egg } \\
w t \\
(g)\end{array}$ & $\begin{array}{c}\text { Food } \\
\text { intake } \\
(\mathrm{g} / \mathrm{d})\end{array}$ & $\begin{array}{l}\text { Water } \\
\text { intake } \\
(\mathrm{ml} / \mathrm{d})\end{array}$ \\
\hline \multicolumn{7}{|l|}{ Expt 1} \\
\hline 0 & 4 & $7 \cdot 3$ & 0.702 & 63.8 & 123 & 225 \\
\hline 2000 & 4 & $46.0^{* * *}$ & 0.728 & $62 \cdot 7$ & 124 & 221 \\
\hline SEM & - & $5 \cdot 85$ & 0.0318 & 0.56 & $1 \cdot 1$ & $3 \cdot 7$ \\
\hline \multicolumn{7}{|l|}{ Expt 2} \\
\hline 0 & 4 & $6 \cdot 2$ & 0.634 & $62 \cdot 7$ & 143 & 234 \\
\hline 600 & 4 & $11.8^{* * *}$ & 0.641 & 62.5 & 144 & 234 \\
\hline 2000 & 4 & $19 \cdot 9 * * *$ & 0.642 & $62 \cdot 3$ & 140 & 238 \\
\hline SEM & - & 0.40 & 0.0031 & 0.61 & $1 \cdot 3$ & $2 \cdot 0$ \\
\hline Diet 1 & 6 & $12 \cdot 0$ & 0.646 & $61 \cdot 2$ & 145 & - \\
\hline Diet 2 & 6 & $14 \cdot 0^{*}$ & $0.631 * *$ & $63 \cdot 1^{*}$ & $140^{*}$ & - \\
\hline SEM & - & $0 \cdot 33$ & 0.0026 & 0.50 & $1 \cdot 0$ & - \\
\hline
\end{tabular}

SEM, Standard error of mean.

Mean values were significantly different from control value: ${ }^{*} P<0.05,{ }^{* *} P<0.01,{ }^{* * *} P<0.001$.

observed on egg production, egg weight, food intake or water intake (Table 1). In Expt 1 soft-shelled egg production averaged $17 \cdot 3 \%$ on the $\mathrm{NaCl}$ treatment compared with $0.8 \%$ from hens receiving unsupplemented drinking water. In Expt 2 egg-shell damage was significantly $(P<0.05)$ greater for hens fed on the breeder crumbles and these hens laid significantly fewer $(P<0.01)$ but larger $(P<0.05)$ eggs and consumed significantly $(P<$ $0.05)$ less food. No significant interactions between the diet and water treatments were observed for any of the measured variables in Expt 2 .

In both experiments the significant increases in egg-shell damage were reflected in significant $(P<0.001)$ reductions in various measures of egg-shell quality (Table 2$)$. In Expt 2 birds fed on the breeder crumbles had significantly poorer egg-shell quality, although the effect was only significant in terms of shell weight: egg weight ratio and shell weight per unit surface area.

Administering $2000 \mathrm{mg} \mathrm{NaCl} / 1$ drinking water significantly $(P<0.001)$ increased the $\mathrm{Na}$ and $\mathrm{Cl}$ concentrations in blood in Expt 1, but no other significant responses in blood variables were observed (Table 3). This level of $\mathrm{NaCl}$ supplementation also increased significantly the concentrations of these ions in shell-gland fluid. In addition, significant decreases in $p_{\mathrm{CO}_{2}}$, and $\mathrm{HCO}_{3}$ and $\mathrm{Ca}$ concentrations, and a significant increase in $\mathrm{pH}$, were observed in the shell-gland fluid of hens treated with $2000 \mathrm{mg} \mathrm{NaCl} / \mathrm{l}$.

At the end of the 5-week experimental period in Expt 2 the mean $p_{\mathrm{CO}_{2}}$ and $\mathrm{HCO}_{3}$, but not $\mathrm{Ca}$, values in the shell-gland fluid of the six hens receiving unsupplemented water and laying eggs with damaged shells, were significantly $(P<0.05)$ lower than the corresponding values for hens receiving the same drinking water and laying eggs with normal shells (Table 4). These variables did not differ significantly due to water treatment among hens laying cracked eggs.

The values in Table 4 indicate that 11 weeks after the removal of $\mathrm{NaCl}$ from the drinking water significant reductions in $p_{\mathrm{CO}_{2}}, \mathrm{HCO}_{3}$ and $\mathrm{Ca}$ were evident in the shell-gland fluid of hens previously receiving $2000 \mathrm{mg} \mathrm{NaCl} / 1$ and laying eggs with damaged shells. Similar 
Table 2. Expts 1 and 2. Mean egg weight and egg-shell quality measurements of laying hens receiving sodium chloride in their drinking water

(Hens were fed on a proprietary layer mash (diet 1) in Expt 1 and either this diet or proprietary layer breeder crumbles (diet 2) in Expt 2; for details of experimental procedures, see pp. 36-37)

\begin{tabular}{|c|c|c|c|c|c|c|}
\hline $\begin{array}{l}\text { Supplement } \\
\text { of } \mathrm{NaCl} \\
(\mathrm{mg} / \mathrm{l})\end{array}$ & $n$ & $\begin{array}{l}\text { Shell } \\
\text { breaking } \\
\text { strength } \\
\text { (g) }\end{array}$ & $\begin{array}{c}\text { Shell } \\
\text { thickness } \\
(\mu \mathrm{m})\end{array}$ & $\begin{array}{l}\text { Shell } \\
\text { wt } \\
(\mathrm{g})\end{array}$ & $\begin{array}{l}\text { Shell wt: } \\
\text { egg wt } \\
(\times 100)\end{array}$ & $\begin{array}{c}\text { Shell wt/unit } \\
\text { surface area } \\
\left(\mathrm{mg} / \mathrm{cm}^{2}\right)\end{array}$ \\
\hline \multicolumn{7}{|l|}{ Expt 1} \\
\hline 0 & 4 & 2044 & 335 & $5 \cdot 59$ & $8 \cdot 65$ & $73 \cdot 7$ \\
\hline 2000 & 4 & $1750^{* * *}$ & $304 * * *$ & $4 \cdot 70^{* * *}$ & $7 \cdot 68 * * *$ & $63 \cdot 7^{* * *}$ \\
\hline SEM & - & $25 \cdot 1$ & $1 \cdot 5$ & 0.042 & 0.085 & $0 \cdot 68$ \\
\hline \multicolumn{7}{|l|}{ Expt 2} \\
\hline 0 & 4 & 2278 & 327 & $5 \cdot 79$ & $9 \cdot 37$ & $78 \cdot 6$ \\
\hline 600 & 4 & $2114^{* * *}$ & $317 * * *$ & $5.05^{* * *}$ & $8 \cdot 07^{* * *}$ & $68 \cdot 6^{* * *}$ \\
\hline 2000 & 4 & $1951^{* * *}$ & $309^{* * *}$ & $4 \cdot 79 * * *$ & $7 \cdot 67^{* * *}$ & $65 \cdot 2^{* * *}$ \\
\hline SEM & - & $23 \cdot 5$ & 0.5 & 0.051 & 0.076 & 0.44 \\
\hline Diet 1 & 6 & 2130 & 318 & $5 \cdot 27$ & $8 \cdot 57$ & $72 \cdot 6$ \\
\hline Diet 2 & 6 & 2098 & 317 & $5 \cdot 15$ & $8 \cdot 18^{* *}$ & $69 \cdot 0^{* * *}$ \\
\hline SEM & - & $19 \cdot 2$ & 0.4 & 0.042 & 0.068 & 0.36 \\
\hline
\end{tabular}

SEM, Standard error of mean.

Mean values were significantly different from control value: ${ }^{* *} P<0 \cdot 01,{ }^{* * *} P<0.001$.

Table 3. Expt 1.† Mean blood and shell-gland fluid measurements of laying hens receiving sodium chloride in their drinking water

\begin{tabular}{|c|c|c|c|c|c|c|c|c|}
\hline $\begin{array}{c}\text { Supplement } \\
\text { of } \mathrm{NaCl} \\
(\mathrm{mg} / 1)\end{array}$ & $n$ & $\mathrm{pH}$ & $\underset{(\mathrm{mmHg})}{p_{\mathrm{Co}}}$ & $\begin{array}{l}\text { Bicarbonate } \\
(\mathrm{mmol} / \mathrm{l})\end{array}$ & $\begin{array}{c}\text { Sodium } \\
(\mathrm{mmol} / \mathrm{l})\end{array}$ & $\begin{array}{c}\text { Potassium } \\
(\mathrm{mmol} / 1)\end{array}$ & $\begin{array}{l}\text { Chloride } \\
(\mathrm{mmol} / \mathrm{l})\end{array}$ & $\begin{array}{c}\text { Calcium } \\
(\mathrm{mmol} / \mathrm{l})\end{array}$ \\
\hline \multicolumn{9}{|l|}{ Blood } \\
\hline 0 & 4 & $7 \cdot 29$ & $51 \cdot 7$ & $23 \cdot 6$ & 147 & $3 \cdot 8$ & 111 & $5 \cdot 6$ \\
\hline 2000 & 6 & $7 \cdot 28$ & $52 \cdot 0$ & $22 \cdot 5$ & $153^{* * *}$ & $4 \cdot 0$ & $120^{* * *}$ & 5.9 \\
\hline SEM & - & 0033 & 4.75 & $1 \cdot 16$ & $1 \cdot 1$ & $0 \cdot 10$ & 1.3 & 064 \\
\hline \multicolumn{9}{|c|}{ Shell-gland fluid } \\
\hline 0 & 4 & $7 \cdot 26$ & $161 \cdot 1$ & $68 \cdot 0$ & $29 \cdot 2$ & $55 \cdot 9$ & $47 \cdot 0$ & $8 \cdot 7$ \\
\hline 2000 & 6 & $7 \cdot 35^{* *}$ & $111 \cdot 7^{* * *}$ & $57 \cdot 8^{*}$ & $39 \cdot 6^{* *}$ & $62 \cdot 0$ & $56 \cdot 8^{*}$ & $6 \cdot 4^{* *}$ \\
\hline SEM & - & 0.014 & $1 \cdot 37$ & $2 \cdot 82$ & 1.97 & $2 \cdot 34$ & 3.04 & 0.42 \\
\hline
\end{tabular}

SEM, Standard error of mean; $p_{\text {co }}$, partial pressure of carbon dioxide.

Mean values were significantly different from control value: ${ }^{*} P<0.05,{ }^{* *} P<0.01,{ }^{* * *} P<0.001$.

$\dagger$ For details, see p. 36 .

reductions were observed in $p_{\mathrm{CO}_{2}}$ and $\mathrm{HCO}_{3}$ concentration in the shell-gland fluid of hens receiving the unsupplemented town tap-water and laying cracked eggs, but the significant reduction in shell-gland $\mathrm{Ca}$ found in the hens receiving $\mathrm{NaCl}$ was not evident in hens receiving the unsupplemented water and laying cracked eggs. The $p_{\mathrm{CO}_{2}}$, and $\mathrm{HCO}_{3}$ and $\mathrm{Ca}$ concentrations in the shell-gland fluid of hens receiving $2000 \mathrm{mg} \mathrm{NaCl} / 1$ and laying normal eggs were not significantly different from the values obtained from hens receiving the unsupplemented water and laying normal eggs. 
Table 4. Expt 2.† Shell-gland fuid measurements of laying hens receiving sodium chloride in their drinking water

(Mean values with their standard errors)

\begin{tabular}{|c|c|c|c|c|c|c|c|c|}
\hline \multirow{2}{*}{$\begin{array}{c}\text { Supplement } \\
\text { of } \mathrm{NaCl} \\
(\mathrm{mg} / \mathrm{l})\end{array}$} & \multirow[b]{2}{*}{$n$} & \multirow{2}{*}{$\begin{array}{c}\text { Egg-type } \\
\text { production }\end{array}$} & \multicolumn{2}{|c|}{$\underset{(\mathrm{mmHg})}{p_{\mathrm{Co}_{3}}}$} & \multicolumn{2}{|c|}{$\begin{array}{c}\text { Bicarbonate } \\
(\mathrm{mmol} / \mathrm{l})\end{array}$} & \multicolumn{2}{|c|}{$\begin{array}{c}\text { Calcium } \\
(\mathrm{mmol} / \mathrm{l})\end{array}$} \\
\hline & & & Mean & SE & Mean & SE & Mean & SE \\
\hline \multicolumn{9}{|l|}{5 weeks } \\
\hline 0 & 10 & Normal & $123 \cdot 3$ & 6.23 & $77 \cdot 6$ & $2 \cdot 32$ & $8 \cdot 5$ & 0.74 \\
\hline 0 & 6 & Cracked & $70 \cdot 5^{*}$ & $21 \cdot 51$ & $53 \cdot 6^{*}$ & 8.58 & $8 \cdot 2$ & $1 \cdot 15$ \\
\hline 2000 & 10 & Cracked & $53 \cdot 2 * * *$ & $6 \cdot 71$ & $47 \cdot 8 * * *$ & 1.68 & $6 \cdot 3 *$ & 0.44 \\
\hline \multicolumn{9}{|l|}{16 weeks } \\
\hline 0 & 10 & Normal & $107 \cdot 9$ & $6 \cdot 21$ & 71.8 & $2 \cdot 88$ & $11 \cdot 6$ & 0.66 \\
\hline 0 & 10 & Cracked & $68 \cdot 8^{* *}$ & $11 \cdot 36$ & $50 \cdot 9^{* * *}$ & 3.82 & $10 \cdot 5$ & 0.97 \\
\hline 2000 & 10 & Normal & $110 \cdot 1$ & 13.37 & $67 \cdot 0$ & $3 \cdot 17$ & $12 \cdot 1$ & 0.88 \\
\hline 2000 & 10 & Cracked & $63 \cdot 4^{* * *}$ & $8 \cdot 34$ & $51 \cdot 9^{* *}$ & $5 \cdot 17$ & $8 \cdot 1 * * *$ & $0 \cdot 35$ \\
\hline
\end{tabular}

Mean values were significantly different from those for hens receiving no $\mathrm{NaCl}$ and laying normal eggs: ${ }^{*} P<$ $0.05, * * P<0.01, * * * P<0.001$.

$\dagger$ For details, see p. 37.

$\mp \mathrm{NaCl}$ treatment given for 5 weeks followed by 11 weeks on normal water.

Table 5. Expt 1.† Changes in physiological aspects of egg production in the oviduct in response to a $2000 \mathrm{mg}$ sodium chloride/ I supplement in the drinking water, and the linear correlation relating these parameters (Y) to the concentration of bicarbonate in shell-gland fluid (X) from the $\mathrm{NaCl}$-treated hens

\begin{tabular}{|c|c|c|c|c|c|c|c|}
\hline & \multirow{2}{*}{\multicolumn{3}{|c|}{$\mathrm{NaCl}$ supplement (mg/l) }} & \multicolumn{3}{|c|}{$Y=B(X)+A$} & \multirow{3}{*}{$\begin{array}{l}\text { Linear } \\
\text { correlation } \\
\text { coefficient } \\
\text { and } \\
\text { statistical } \\
\text { significance }\end{array}$} \\
\hline & & & & \multicolumn{2}{|c|}{$B$} & \multirow[t]{2}{*}{$A$} & \\
\hline & 0 & 2000 & SEM & Mean & $\mathrm{SE}$ & & \\
\hline Shell damage (/100 hens) & $7 \cdot 3$ & $46-0^{* * *}$ & $5 \cdot 85$ & $-2 \cdot 07$ & 0.535 & $162 \cdot 7$ & $-0.89 *$ \\
\hline Mean eggs/clutch & 3.8 & 41 & 0.23 & -0.03 & 0.029 & $5 \cdot 79$ & -0.43 \\
\hline $\begin{array}{l}\text { Arithmetic mean of } \\
\text { oviposition intervals } \\
\text { within a clutch (h) }\end{array}$ & $26 \cdot 4$ & $25 \cdot 0^{*}$ & $0 \cdot 40$ & $0 \cdot 14$ & 0.033 & $17 \cdot 56$ & $0 \cdot 91^{*}$ \\
\hline $\begin{array}{l}\text { Cumulative delay in } \\
\text { oviposition within } \\
\text { clutches of more than } \\
\text { two eggs (h) } \ddagger\end{array}$ & $4 \cdot 7$ & $1 \cdot 4^{*}$ & $0 \cdot 90$ & $0 \cdot 38$ & $0 \cdot 160$ & $-20 \cdot 60$ & $0 \cdot 77$ \\
\hline $\begin{array}{l}\text { Eggs laid during first } 5 \mathrm{~h} \\
\text { of daylight (/100 eggs) }\end{array}$ & $43 \cdot 3$ & $56 \cdot 7^{*}$ & $3 \cdot 20$ & $-0 \cdot 25$ & 0.039 & $70 \cdot 6$ & $-0.95^{* *}$ \\
\hline$n$ & 4 & 6 & - & - & - & - & - \\
\hline
\end{tabular}

SEM, Standard error of mean.

${ }^{*} P<0.05,{ }^{* *} P<0.01,{ }^{* * *} P<0.001$.

$\uparrow$ For details, see p. 36 .

$\$$ A delay of $0 \mathrm{~h}$ means an interval of $24 \mathrm{~h}$ between eggs. 
In Expt 1 the arithmetic mean of the oviposition intervals within a clutch and the cumulative delay in oviposition times within clutches of more than two eggs were significantly $(P<0.05)$ shorter for hens receiving the $\mathrm{NaCl}$ supplement in the drinking water (Table 5). These hens laid significantly $(P<0.05)$ more eggs during the first $5 \mathrm{~h}$ of daylight. The degree of egg-shell damage and the numbers of eggs laid during the first 5 $\mathrm{h}$ of daylight were negatively correlated, and the oviposition values positively correlated, with the $\mathrm{HCO}_{3}$ ion concentration in shell-gland fluid (Table 5).

\section{DISCUSSION}

The present results confirm those of earlier studies (Balnave \& Scott, 1986; Balnave \& Yoselewitz, 1987; Yoselewitz et al. 1988) which showed that supplementing the drinking water of laying hens with $\mathrm{NaCl}$ increases the incidence of egg-shell damage without having any significant influence on egg production, egg weight or food and water intakes. In the present studies hens receiving $600 \mathrm{mg} \mathrm{NaCl} / 1$ obtained approximately $20 \%$ of their total $\mathrm{Na}$ and $\mathrm{Cl}$ intakes from the drinking water. In the case of the $2000 \mathrm{mg} \mathrm{NaCl} / 1$ supplement this value was increased to approximately $45 \%$.

In our early studies carried out in commercial facilities with water supplements of up to $600 \mathrm{mg} \mathrm{NaCl} / 1$ (Balnave \& Scott, 1986; Balnave \& Yoselewitz, 1987) we failed to observe any significant production of soft-shelled (shell-less) eggs. However, in Expt 1 of the present study, and in two other recent experiments where we have administered $2000 \mathrm{mg} \mathrm{NaCl} / 1$ to laying hens in individual cages fitted with excreta collection trays, soft-shelled egg production was 17.3 (present Expt 1), 9.7 and $31.3 \%$ respectively compared with less than $1 \%$ in hens receiving normal drinking water. These findings show that this relatively high concentration of $\mathrm{NaCl}$ in the drinking water affects the metabolism of some hens so severely that they are unable to deposit a shell on the egg during its passage through the oviduct. Under commercial conditions these eggs go undetected because of loss through the cage floors.

The significantly greater egg-shell damage observed with hens fed on the breeder crumbles indicates that the problem is not associated either with physical separation of dietary components or with hens choosing not to eat the Ca component in the layer mash. The increased incidence of shell damage in hens fed on the breeder crumbles may be associated with the significantly lower food intake and significantly larger eggs produced by hens on this feed.

In agreement with previous observations, the increased egg-shell damage resulting from the use of saline drinking water was associated with reductions in a range of measurements of egg-shell quality. However, it is evident from the present work that the higher incidence of egg-shell defects from hens receiving $\mathrm{NaCl}$ was not reflected in major changes in blood acid-base balance and electrolytes. Although significant increases in the $\mathrm{Na}$ and $\mathrm{Cl}$ concentrations occurred as a result of the $\mathrm{NaCl}$ treatment, no other major changes in blood variables were detected. This confirms the results of previous work (Yoselewitz et al. 1988) and indicates that the problem is not caused by a failure to absorb nutrients from the digestive tract.

Most studies with dietary $\mathrm{Cl}$ supplements have reported a negative relation between dietary $\mathrm{Cl}$ concentrations and blood $\mathrm{HCO}_{3}$ (Hunt \& Aitken, 1962; Cohen \& Hurwitz, 1974; Hamilton \& Thompson, 1980), although such a response to saline drinking water has not been noticed by us in the present, or previous work (Yoselewitz et al. 1988). However, Hamilton \& Thompson (1980) failed to observe any effect of dietary $\mathrm{Cl}$ on shell quality and Hunt \& Aitken (1962) found no noticeable change in plasma Ca. Austic \& Keshavarz 
(1984) found that dietary $\mathrm{Cl}$ supplementation depressed egg-shell strength and thickness only when dietary $\mathrm{Ca}$ was limiting for egg-shell formation.

Our present results indicate that the biological lesion resulting from the use of saline drinking water is associated with the supply of $\mathrm{HCO}_{3}$ and $\mathrm{Ca}$ to the lumen of the shell gland rather than to inadequate supplies of these nutrients in the blood. The increases in the concentrations of $\mathrm{Na}$ and $\mathrm{Cl}$ in the blood were reflected in similar increases in shellgland fluid but, in addition, significant reductions were observed in the $p_{\mathrm{CO}_{2}}$, and $\mathrm{HCO}_{3}$ and $\mathrm{Ca}$ concentrations in shell-gland fluid. These results are not inconsistent with the concept that metabolic $\mathrm{CO}_{2}$ is the source for at least some of the $\mathrm{HCO}_{3}$ needed for egg-shell formation (Lorcher et al. 1970). In this regard, the activity of carbonic anhydrase (EC 4.2.1.1), necessary for the hydration of $\mathrm{CO}_{2}$ to produce $\mathrm{HCO}_{3}$ ions in the shell gland, is much greater in laying than in non-laying birds (Pearson et al. 1977) and in birds laying normal eggs compared with birds laying soft-shelled eggs (Gutowska \& Mitchell, 1945).

Our earlier studies indicated that saline drinking water influenced metabolism in a way that permanently affected the ability of some hens to produce normal egg-shells (Balnave \& Yoselewitz, 1987). Hens affected in this way did not recover the ability to lay eggs with normal shells even when the $\mathrm{NaCl}$ was removed from the drinking water (Balnave \& Scott, 1986; Balnave \& Yoselewitz, 1987). A similar response was found in Expt 2 where hens given normal water for $8-11$ weeks after the end of the $\mathrm{NaCl}$ treatment continued to show a high incidence of shell defects on both diets. The production of eggs with damaged shells during these 4 weeks amounted to $5.9,11.3$ and $17.2 \%$ respectively for hens previously receiving 0,600 and $2000 \mathrm{mg} \mathrm{NaCl} / \mathrm{l}$; values similar to those observed during the period of $\mathrm{NaCl}$ treatment.

The individual nature of the response to $\mathrm{NaCl}$ was confirmed by the measurements made on shell-gland fluid in Expt 2. These findings clarify previously reported observations (Yoselewitz et al. 1988) that hens laying cracked eggs on 0 and $600 \mathrm{mg} \mathrm{NaCl} / 1$ treatments produced eggs with similar shell-quality characteristics, inferior to those of hens on either treatment producing eggs with normal shells. The present findings also indicate that, although saline drinking water may have a specific influence on $\mathrm{Ca}$ supply, poor egg-shell quality may be associated more with a lack of supply of $\mathrm{HCO}_{3}$ ions, rather than $\mathrm{Ca}$ ions, to the lumen of the shell gland. It is possible that the supply of both ions may be interdependent since Pearson et al. (1977) have suggested that Ca transport across the avian shell gland is related to the activity of carbonic anhydrase in this tissue and Eastin \& Spaziani (1978) have reported a dependency of Ca secretion on lumen $\mathrm{HCO}_{3}$ concentration and $\mathrm{HCO}_{3}$ production. Inhibition of carbonic anhydrase interferes with egg-shell deposition and quality (see Pearson et al. 1977).

Part of the explanation for the reductions we have observed in egg-shell quality in these and in previous studies may be derived from the values in Table 5. Increases in egg-shell damage, and in egg production during the early part of the day, were negatively correlated with the concentration of $\mathrm{HCO}_{3}$ ions in the shell gland fluid, i.e. positively correlated with the concentration of $\mathrm{NaCl}$ in the drinking water. Similarly, increases in the residence time of eggs in the oviduct, as reflected in mean oviposition interval within a clutch and the cumulative delay in oviposition times within clutches, were positively correlated with shellgland $\mathrm{HCO}_{3}$ concentration and, therefore, negatively correlated with the concentration of $\mathrm{NaCl}$ in the drinking water. A reduction in the time that eggs remain in the shell gland would influence the amount of calcium carbonate deposited as shell as well as explaining the earlier daily oviposition times. However, this is not the complete answer as evidenced by the tendency for soft-shelled-egg production which shows that a basic biological lesion in $\mathrm{CaCO}_{3}$ formation in the shell gland exists in these birds. It appears that the procedure 
of supplementing drinking water with $\mathrm{NaCl}$ may prove a suitable model for conducting basic studies relating to egg-shell formation in poultry.

Finally, an underlying, unrecognized cause of poor egg-shell quality, such as identified in our recent studies, may explain why extensive attempts to overcome the problem in commercial flocks has proved unsuccessful. This is accentuated in many countries by the wide use of underground water supplies containing dissolved salts, including $\mathrm{NaCl}$, as sources of drinking water and the fact that the response is noticeable with relatively low $(200 \mathrm{mg} / \mathrm{l})$ concentrations of $\mathrm{NaCl}$ (Balnave \& Yoselewitz, 1987). In addition, the problem does not respond to Ca supplementation of the diet (Yoselewitz et al. 1988) and it is evident from the present and other studies (Balnave \& Scott, 1986; Balnave \& Yoselewitz, 1987) that permanent damage is done to the egg calcification process in individual birds.

The present work was supported by the Poultry Research Foundation, University of Sydney and the Poultry Research Council which provided a postgraduate scholarship for one of us (I. Y.).

\section{REFERENCES}

Austic, R. E. \& Keshavarz, K. (1984). Dietary electrolytes and egg shell quality. In Proceedings of the Cornell Nutrition Conference for Feed Manufacturers, pp. 63-69. Cornell University: Ithaca.

Balnave, D. \& Scott, T. (1986). The influence of minerals in drinking water on egg shell quality. Nutrition Reports International 34, 29-34.

Balnave, D. \& Yoselewitz, I. (1987). The relation between sodium chloride concentration in drinking water and egg-shell damage. British Journal of Nutrition 58, 503-509.

Cohen, I. \& Hurwitz, S. (1974). The response of blood ionic constituents and acid-base balance to dietary sodium, potassium and chloride in laying fowls. Poultry Science 53, 378-383.

Eastin, W. C. \& Spaziani, E. (1978). On the mechanism of calcium secretion in the avian shell gland (uterus). Biology of Reproduction 19, $505-518$.

El Jack, M. H. \& Lake, P. E. (1967). The content of the principal inorganic ions and carbon dioxide in uterine fluids of the domestic hen. Journal of Reproduction and Fertility 13, 127-132.

Gutowska, M. S. \& Mitchell, C. A. (1945). Carbonic anhydrase in the calcification of the egg shell. Poultry Science 24, $159-167$.

Hamilton, R. M. G. \& Thompson, B. K. (1980). Effects of sodium plus potassium to chloride ratio in practicaltype diets on blood gas levels in three strains of White Leghorn hens and the relationship between acid-base balance and egg shell strength. Poultry Science 59, 1294-1303.

Hunt, J. R. \& Aitken, J. R. (1962). The effect of ammonium and chloride ions in the diet of hens on egg shell quality. Poultry Science 41, 434. 438.

Lorcher, K., Zscheile, C. \& Bronsch, K. (1970). Transfer of continuously i.v. infused $\mathrm{NaHC}^{14} \mathrm{O}_{3}$ and $\mathrm{Ca}^{47} \mathrm{Cl}_{2}$ to the hens egg shell. Annales de Biologie Animale Biochimie Biophysique 10, 193-198.

Pearson, T. W., Pryor, T. J. \& Goldner, A. M. (1977). Calcium transport across avian uterus. III. Comparison of laying and nonlaying birds. American Journal of Physiology 232, E437-E443.

Steel, R. G. D. \& Torric, J. H. (1982). Principles and Procedures of Statistics. Kogakusha, Tokyo: McGrawHill.

Yoselewitz, I., Balnave, D. \& Dixon, R. J. (1988). Factors influencing the production of defective egg shells by laying hens receiving sodium chloride in the drinking water. Nutrition Reports International. (In the press.) 